\title{
School Climate : A Quantitative Study of Middle School Students in Vietnam
}

\section{TRAN Thu Huonga, NGO Thanh Hue ${ }^{\mathrm{b}}$, and NGUYEN Hanh Lien ${ }^{\mathrm{c}}$}

${ }^{a}$ Department of Psychology, Faculty of Social Sciences and Humanities, Vietnam National University, Hanoi, Vietnam; ${ }^{b}$ International School, Vietnam National University, Hanoi, Vietnam; ${ }^{C}$ Department of Psychology, Faculty of Social Sciences and Humanities, Vietnam National University, Hanoi, Vietnam

*Corresponding author :

Tran Thu Huong

Department of Psychology

Faculty of Social Sciences and Humanities

Vietnam National University

Hanoi, Vietnam

Email address : tranthuhuong@ussh.edu.vn / huonghn1978@gmail.com 


\title{
School Climate : A Quantitative Study of Middle School Students in Vietnam
}

\begin{abstract}
This study aimed to understand the general perception of the term 'school climate' as well as its specific dimesions using Randolph, Kangas \& Ruokamo's (2009) model as its theoretical basis. The NJSCS-MSHS scale (New Jersey School Climate Survey Middle - High School Students in 2014) was employed by this study to accomplish an evaluation by a sample of 535 middle school students in Hanoi, Vietnam. The participants, $50.6 \%$ of whom were boys with girls accounting for $49.4 \%$, were aged between 12 and 14 years. The descriptive analyses conducted proved that of the main dimensions that determine school climate, social relationships, physical environments, and emotional atmosphre are three aspects that do not evoke satisfaction among students. Relationships between students were also found to exert an impact on academic performance and the practices adopted by teacher extended both physical and emotional effect. The principles of the school community with regard to safety were also influential to the adjudication of the school climate. In summary, the satisfaction or happiness with the school environment was not subject to the domination of the quality of school friendships or to the issue of school safety; the school climate was found to be especially and intimately related to the teaching and learning activities and practices that prevailed in the school.
\end{abstract}

Keywords : satisfaction at school, school climate, Vietnamese middle high school

\section{Introduction}

The middle school is not merely a place where students come to learn; it is also an environment where a process of socialization is instituted, through which these young subjects develop their soft skills, build their community relationships, develop their self-esteem, and establish their future goals. The experiences students encounter at middle school are therefore pivotal to their quality of life and particularly to their personal development (Danielsen, Samdal, Hetland, \& Wold, 2009). Previous research projects have evidenced that children who inculcate a sense of well-being from a good school climate develop healthy adaptation strategies for life and also increase their abilities and their potential for academic success. Conversely, students who grow without such a sense of welfare present discrete physical and psychological difficulties (Randolph, Kangas, Roukamo, 2009) and are less comfortable than others in terms of quality of life.

This article intends to use statistical data pertaining to middle school students to provide an overview of the sense of well-being and the school climate as perceived by the young subjects of the investigation. The different dimensions of school climate are also specified in this paper, which contributes to the scholarly literature through its elucidation of the concept and its components. Furthermore, the results of this study provide practical recommendations that will eliminate the need for experts to rely only on previously accumulated Western theoretical knowledge. At the practical level, the present study offers the potential of yielding proposals for strategies to improve the conditions that prevail in Vietnamese schools in the aim to foster a better school climate that is conducive to the well-being of middle school students in Vietnam. 


\section{A. Notion of well-being : A multi-dimensional concept}

The Vietnamese translation of the term "bien-être" (French) or "well-being" (English) is multifaceted in its meaning. However, in the Western (English/French) concept, the sense of wellbeing incorporates three dimensions: good physical condition, a state of psychic gratification, and the position of satisfying material needs.

According to the authors of previous studies, there are two types of well-being: happiness (eudemonisme) that emanates from the satisfaction of self-actions to accomplish one's life's mission and reason for living; and pleasure (hedonism) that is derived from the satisfaction of the simple demands of daily life (Slee \& Skrzypiec, 2016). Thus, the concept of well-being evokes two aspects of satisfaction: the fulfillment of material needs for existence, and the spiritual contentment that originates from self realization.

It is not easy to find a Vietnamese word that can articulate all the above dimensions. However, some authors use terms that denote happiness, peace, and gratification (Truong Thi Khanh Ha, 2015; Le Ngoc Van, 2018). These words are also used fluently for Buddhist principles or for positive psychology. It is important to unify the intrinsic nature of the concept and the terminology that is used to denote it. From the above-mentioned similarities, the term "wellbeing" is used as "happiness" and is defined as the experience of a set of feelings of peace and gratification in human beings. This definition includes the physical and mental well-being and the material insurance for survival.

\section{B. Well-being in schools}

The sense of well-being at school contributes to the general feeling of welfare in children. The activities and experiences children encounter long before transitioning to adulthood are often associated with their schools. However, scholars have defined the nature and components of the notion of well-being at school in very different ways (Guimard, Bacro \& Florin, 2013).

Indeed, numerous previous studies have referred to this idea. First of all, it has been emphasized that the overall objectives attributed to education and training must not just address the development of life competencies in people, even though these goals are essential. Education and training should, in fact, develop people holistically and should drive them toward achieving their full potential, leading people to live a full existence and to participate actively in social and economic activities. Several studies in France have demonstrated the value of regarding children as actors in their own development and helping them develop their perception, expression, and social abilities. Such education is interested primarily the well-being of the child in a world that is becoming increasingly more difficult to negotiate in its social, economic, and technological dimensions. If these aspects are not attended to in schools, they become a major challenge later for the education and training of adults (Florin, 2011a; Florin, 2011b). In reality, many educational systems nowadays believe that the success of students does not merely relate to their academic performance, but shows in the sense of well-being they feel in their life, and especially in schools. On the other hand, schools are considered pivotal locations for the socialization of children and as places where children develop their personal convictions and values along with 
their educational and professional goals (Karatzias, Power, Flemming, Lennan, \& Swanson, 2002).

A child's experiences at schools can affect the personal development and the overall quality of the child's life (Danielsen, Samdal, Hetland, \& Wold, 2009). Various studies have indicated that students who are satisfied with life at school are more able to develop strategies for adaptation, to increase their personal resources, and engage successfully with the learning process. Conversely, students who are comparatively dissatisfied with the school environment tend to demonstrate lower satisfaction levels with life in general and run into more risk of encountering more difficulties, both physically and psychologically (Randolph, Kangas \& Ruokamo, 2009). As a result, well-being of children in the school environment becomes an important variable: it is related to other variables relevant to the social adaptation of children; and it also concerns glocal education for the future of the individual; for holistic personal development, for the enhancement of social relationships, and for the amelioration of the overall quality of a child's life (Gibbons \& Silva, 2011).

Although not much research has yet been conducted on this issue, the theme of well-being at school and satisfaction with the school environment seems to have become a supplemental object of research that is being conducted on more traditional themes and that emphasize the interpretative factors of school results.

The definition of well-being has not been suitably discussed because the majority of researchers believe that students are precisely poised to assess their well-being. In the school environment, well-being and quality of life are appreciated either in terms of the level of happiness with regard to the school, or as the result of a set of specific features such as the classroom climate, the process of regrouping students, the perception of competence, and so on (Randolph, Kangas, Ruokamo, 2009). However, the number of elements that are considered and the nature of the studied aspects are not equivalent in the different points of view and the reasons that result in this discrepancy are rarely elucidated.

Randolph, Kangas, and Roukamo's model (2009) indicates that overall well-being (quality of life) includes the positive appreciation of life satisfaction and the lack of negative attitudes to oneself and one's family, school, friends, and living environment. In particular, the sense of well-being at school is defined as the level of satisfaction of students with regard to the overall dimensions such as a comprehensive feeling of satisfaction from the school, the school climate, the intelligence and the grouping of students, and the academic success. In fact, the school climate also incorporates the relational aspects, the school's activities, and the feeling of safety and security.

\section{The school climate : A principal dimension of well-being in schools}

The notion of school climate has become popular in the global context but it is not adequately addressed in the Vietnamese cultural context. It is evident that the improvement of the school climate is accepted as an effective condition of educational systems. 
A large number of scientific researchers have evidenced a very strong link between school climate, learning quality, academic success, and victimization at school premises. Indeed, the school climate is considered to be an object of systematic studies since the 1950s, and has witnessed a strong acceleration as the topic of research in many countries. However, a univocal and consensual definition of the school climate still does not exist (Debarbieux, et al., 2012).

The school climate in general includes the norms, values, and quality of the interpersonal relationships, the educational and learning practices, and the institutional structures of a school. According to Anderson (1982), it is very difficult to define the school climate. A frequent confusion occurs between the terms school climate and school safety. The quality and style of school life are not merely shaped by the fact of feeling or not feeling safe within its perimeters; it also encompasses the engagement, the motivation, and the gratification of students who form part of the school's body. Cohen and his colleagues (2009, in Debarbieux, 2015) claim that the school climate reflects the judgment that is created in parents, educators, and students from their experiences of life and work in the school environment. As a result, it is not a simple matter of individual perception. This notion of "climate" is based on the subjective experience of school life which takes into account not just the individual but the school as a large group and also the different social groups within the school (Debarbieux, 2015).

Theoretically, some scholars agree generally to the claim that a good school climate is characterized by the warmth of interpersonal relationships, the institution's system of clear and coherent rules, and a low rate of victimization (Purkey \& Smith, 1983; Rutter, 1983; Gottfredson \& Gottfredson, 1985). Others also mention aspects that are more concerned with the tasks and the learning process (Fraser, 1990; Taylor, Fraser and Fisher, 1997). Despite the diversity of theoretical referents summoned for use as research methodologies, the studies so far conducted on the school climate evince that the dimension of interpersonal relationships is a determinant component that strongly influences health and learning processes. A favorable environment creates the orientation for good relations and strengthens the well-being, academic self-esteem, the formation of friendships, and the academic success of children while a conflicting atmosphere causes a negative impact on the sentiments of security, self-esteem, learning processes, and school performance (Samdal, Nutbeam, Wold, \& Kannas, 1998; Dorman, 2002; Bennacer, 2008).

According to the School Climate Center (Cohen, McCabe \& al., 2009 in Debarbieux, 2015), "the school climate refers to the quality and the style of life at school. The school climate is based on the models that have individuals from their life experience at school. It reflects norms, goals, values, interpersonal relationships, practices of teaching, learning and management, and organizational structure included in the school life" (pp. 13). For these researchers, the school climate consists of five elements: 1) relationships (respect for diversity; school community, and collaboration); 2) teaching and learning processes (quality of education; social, emotional and ethical learning; professional development; and leadership); 3) safety (physical and emotional security); 4) physical environment (cleanliness, adequate space and equipment, aestheticism, and extracurricular activities); 5) the sentiment of belonging (the sense of connectedness to the school community; the feeling of being attached to an adult, at least for 
students; commitment; and the enthusiasm of teachers and students). These five elements are measured by following factors:

- A significant participation of students with their peers and their teachers in school activities;

- The reaction of confronting psychological problems/ difficulties in school environment;

- An attention devoted by the school to the student's family life (inculcating respect for adults in the school environment helps improve the family culture of students).

The originality of this study pertains to its focus on middle school students whose perceptions of the school climate are already adequately known and explored. This research aims to study the school climate with regard to its quality of learning and academic success. The investigation is performed in Vietnam, where the conception of life and the economic and cultural circumstances are very different to the Western countries. The present study goes beyond the question on the effects of the school climate on the academic performance or safety of students to ask: "What components of the school climate are associated with what aspects of school performance or safety?"

\section{Research Methods}

\section{A. Research population}

This cross-sectional study was conducted in September 2017 on a sample $(N)$ comprising 535 Vietnamese middle school students selected through the practical sampling method from four middle schools located in the Cau Giay and Ba Vi districts in Hanoi, Vietnam. The pilot study at a middle school in Dong Da district, Hanoi in April 2017 engaged 149 students who were 12-13 years-old.

The response time for each student was 30 minutes. The data collection was accomplished by the researchers and their collaborators who were the teachers in the school in classes during the meeting. The characteristics of the sample of research are described in the Table 1 below:

Table I. Characteristics of Research Sample

\begin{tabular}{|l|l|l|l|}
\hline \multicolumn{2}{|l|}{ Variables } & Effectif & Percentage \\
\hline \multirow{2}{*}{ Sex } & Boys & 261 & 50,6 \\
\cline { 2 - 4 } & Girls & 255 & 49,4 \\
\hline \multirow{4}{*}{$\begin{array}{l}\text { Academic } \\
\text { level }\end{array}$} & High Distinction & 69 & 13,4 \\
\cline { 2 - 4 } & Distinction & 170 & 32,9 \\
\cline { 2 - 4 } & Fair & 207 & 40,1 \\
\cline { 2 - 4 } & On average & 70 & 13,6 \\
\hline \multirow{3}{*}{ Classes } & 7th & 149 & 28,2 \\
\cline { 2 - 4 } & 8th & 162 & 30,6 \\
\cline { 2 - 4 } & 9th & 218 & 41,2 \\
\hline \multirow{5}{*}{} & C.G. middle high school & 110 & 20,6 \\
\cline { 2 - 4 } & C.D. middle high school & 144 & 26,9 \\
\cline { 2 - 4 } & & & \\
\cline { 2 - 4 } & D.V. middle high school & 155 & 29,0 \\
\hline
\end{tabular}




\begin{tabular}{|l|l|l|l|}
\hline & P.C. middle-high school & 126 & 23,6 \\
\hline $\begin{array}{l}\text { Place of } \\
\text { living }\end{array}$ & In the city & 200 & 39,1 \\
\cline { 2 - 4 } & Suburban & 312 & 60,9 \\
\hline
\end{tabular}

\section{B. Data Analysis}

The quantitative approach was applied to an adapted version of the questionnaire designed and developed by the University of New Jersey in 2014 (NJSCS-MSHS: New Jersey School Climate Survey Middle - High School Students). Its structure was not affected, and it was merely simplified for application to Vietnamese middle high school students. This modified questionnaire was validated before it was administered to the middle school students. It comprised 48 items pertaining to 7 main themes including: 1) the physical environment (3 items); 2) the teaching and learning process (11 items); 3) the morale of the school community (9 items); 4) the student relationships (4 items); 5) parental support (3 items); 6) safety (4 items); and 7) the emotional ambiance (feeling of belonging) (14 items).

The satisfaction levels of students for each field were rated on a 5-point scale with the following values: 1 = Strongly disagree, 2 = Disagree, 3 = Partially agree, $4=$ Agree, $5=$ Strongly agree. The scores for each field represented a value ranging from 0 to 100 , which were calculated from the responses to the survey. A score higher or lower could relate to the positive or negative perception of the school environment depending on the wording of the question. The score distribution of a domain was depicted in the form of a line chart representing the distribution of individual responses from students, grouped into deciles. The line would be higher if more students were placed at a particular ranking, or lower if fewer students were placed at that position.

The data were treated through a copyright version of the SPSS 24.0 and through MS-Excel (especially for the NJSCS-MSHS questionnaire). Descriptive statistical analyses were performed initially to consider the assessment of the dimensions of school well-being by students. Second, the links between the quantitative variables were studied through comparisons of mean $(M)$ for a number of variable categories and depending on the verification of applied conditions, different tests were used: The Independent Sample T-test was applied for the variables in two ways, and the one-way ANOVA was used for several factors. The 5\% significance threshold was adopted in all cases.

\section{Results}

\section{A. Physical environment at school is not appreciated}

Table II. Mean Score and Frequency of Students' Responses in the Domain of Physical Environment

\begin{tabular}{|c|c|c|c|c|c|c|c|}
\hline \multirow{3}{*}{$\begin{array}{l}\text { Question } \\
\text { Items }\end{array}$} & \multicolumn{7}{|c|}{ DOMAIN: Physical environment Score $=57,8$} \\
\hline & \multicolumn{5}{|c|}{ Response category $(\mathrm{N} / \%)^{\mathrm{a}}$} & \multirow{2}{*}{$\begin{array}{c}M / \\
M D\end{array}$} & \multirow[t]{2}{*}{ SD } \\
\hline & 1 & 2 & 3 & 4 & 5 & & \\
\hline \multirow{3}{*}{$\begin{array}{l}\text { The length of } \\
\text { the school day } \\
\text { is about right }\end{array}$} & 31 & 25 & 155 & 232 & 86 & \multirow{2}{*}{$\begin{array}{l}3.60 \\
4.00\end{array}$} & \multirow[t]{2}{*}{1.01} \\
\hline & 5,9 & 4,7 & 29,3 & 43,9 & 16,3 & & \\
\hline & 28 & 87 & 236 & 127 & 51 & 3.16 & 0.99 \\
\hline
\end{tabular}




\begin{tabular}{|l|l|l|l|l|l|l|l|}
\hline $\begin{array}{l}\text { My school is } \\
\text { kept clean }\end{array}$ & 5,3 & 16,4 & 44,6 & 24,0 & 9,6 & 3.00 & \\
\hline $\begin{array}{l}\text { I like my } \\
\text { school building }\end{array}$ & 29 & 64 & 119 & 176 & 140 & 3.63 & 1.16 \\
\cline { 2 - 8 } & 5,5 & 12,1 & 22,5 & 33,3 & 26,5 & 4.00 & \\
\hline M of the domain
\end{tabular}

*1. Strongly disagree; 2 . Disagree; 3 . Partially agree; 4. Agree; 5. Strongly agree

The results shown in Table 2 evince that the research subjects expressed a neutral attitude toward the physical environment of their school, with $M=3.46, S D=0.79$. This uncertain outlook translates into the fact that students neither like nor dislike the school buildings $(M=$ $3.63, S D=1.16$ ); However, $59.8 \%$ of the respondents recorded that they like or really like the construction of their school). Approximately one in five students $(22.5 \%)$ provided unspecified answers, exhibiting that they do not espouse any obvious attitudes toward the structure of their school. Beyond these results, it is elucidated that in general, students do not appreciate the sanitary aspects of their school $(M=3.16, S D=0.99)$.

In responding to the item "My school is kept clean," $21.7 \%$ of the students claimed that their school was not clean and $44.6 \%$ did not know whether or not their school was hygienic. Thus, sanitation is probably an alarming issue for Vietnamese schools at in general. Students expressed a clearer position in answer to the question related to their school day $(M=3.60, S D$ $=1.01$ ), with $43.9 \%$ approving of the duration and $16.3 \%$ agreeing completely with this statement. However, it is noteworthy that nearly one-third of the respondents (equivalent 29.3\%) did not know or did not take an interest in the hours they spent at school.

The total score of the physical environment domain was computed to be 57.8 out of a possible 100. This figure indicates that $19.63 \%$ of the respondents were placed at the interval between 50 and 60 points. However, the results illustrated in Fig. 1 indicate that $17.18 \%$ of the students were ranked between 40 and 50 points and that $9.82 \%$ were calculated to be in the range of 30 to 40. These data reflect that around $30 \%$ of students believe that the physical environment of their school is below its value $M$ and $68.71 \%$ think that it is above this value, including $42.33 \%$ who registered between 60 to 80 points and $6.75 \%$ who were placed at the level between 80 and 90. This outcome reaffirms the initial statement that students are not satisfied with the material and environmental situation of their school.

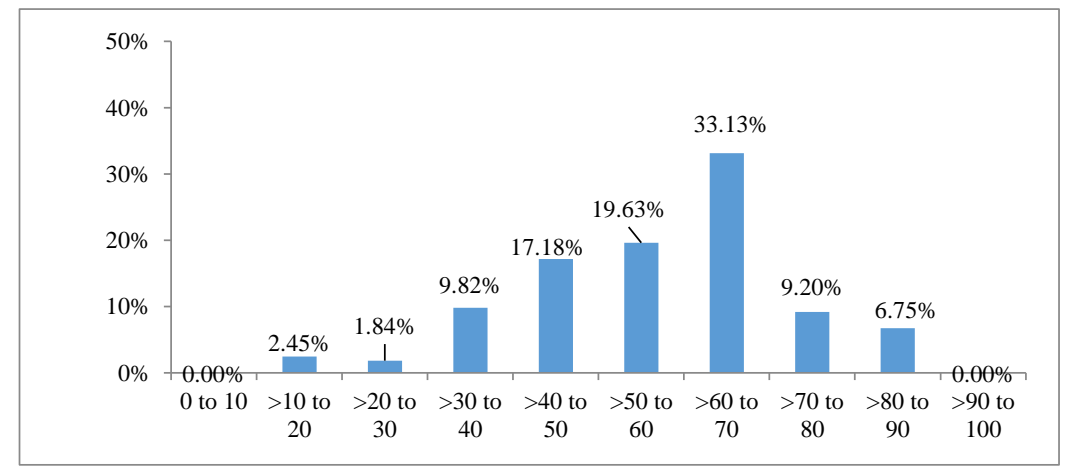

Fig. 1. Score distribution (in deciles) in the domain of physical environment 
The results obtained from the one-way analysis of variance (ANOVA) indicate a statistically significant difference $(p<.05)$ between subgroups of students at different academic levels with respect to their satisfaction with the physical environment of their school. Students at the distinction level $(M=3.71, S D=0.92)$ were more satisfied with the time spent in school activities than those with excellent academic performance $(M=3.31, S D=1.21)$. Students in C.G. middle school $(M=3.32, S D=0.99)$ and C.D. middle school $(M=3.18, S D=1.21)$ were less satisfied $(p<.05)$ with the way in which their school buildings were constructed than the students of D.V. school $(M=3.97, S D=1.13)$ and P.C. school $(M=4.00, S D=1.00)$. New students (7th grade) registered higher satisfaction with the cleanliness of their school and with the school buildings than the older classes ( 8 th and $9^{\text {th }}$ grades). This statistically significant difference was determined at $p=.031$. No statistically significant differences were found between subgroups of students based on other values such as sex, or place of residence.

\section{B. Impact of the practices of teachers}

Table III. Mean Score and Frequency of Students' Responses in the Domain of Teaching and Learning

\begin{tabular}{|c|c|c|c|c|c|c|c|}
\hline \multirow{3}{*}{ Question Items } & \multicolumn{7}{|c|}{ DOMAIN: Teaching and learning Score $=65,1$} \\
\hline & \multicolumn{5}{|c|}{ Response category $(\mathbf{N} / \%)^{\mathrm{a}}$} & \multirow{2}{*}{$\begin{array}{c}M / \\
M D\end{array}$} & \multirow[t]{2}{*}{$S D$} \\
\hline & 1 & 2 & 3 & 4 & 5 & & \\
\hline \multirow{2}{*}{$\begin{array}{l}\text { My teachers give me a lot of } \\
\text { encouragement }\end{array}$} & 25 & 31 & 154 & 198 & 118 & \multirow{2}{*}{$\begin{array}{l}3.67 \\
4.00\end{array}$} & \multirow[t]{2}{*}{1.04} \\
\hline & 4,8 & 5,9 & 29,3 & 37,6 & 22,4 & & \\
\hline \multirow{2}{*}{$\begin{array}{l}\text { My teachers make learning } \\
\text { interesting }\end{array}$} & 22 & 35 & 204 & 170 & 95 & \multirow{2}{*}{$\begin{array}{l}3.53 \\
4.00\end{array}$} & \multirow[t]{2}{*}{1.00} \\
\hline & 4,2 & 6,7 & 38,8 & 32,3 & 18,1 & & \\
\hline \multirow{2}{*}{$\begin{array}{l}\text { My teachers encourage students } \\
\text { to share their ideas about things } \\
\text { we are studying in class }\end{array}$} & 22 & 41 & 142 & 223 & 96 & \multirow{2}{*}{$\begin{array}{l}3.63 \\
4.00\end{array}$} & \multirow[t]{2}{*}{1.00} \\
\hline & 4,2 & 7,8 & 27,1 & 42,6 & 18,3 & & \\
\hline \multirow{2}{*}{$\begin{array}{l}\text { My teachers notice when I am } \\
\text { doing a good job and let me } \\
\text { know about it. }\end{array}$} & 28 & 84 & 171 & 166 & 72 & \multirow{2}{*}{$\begin{array}{l}3.33 \\
3.00\end{array}$} & \multirow[t]{2}{*}{1.07} \\
\hline & 5,4 & 16.1 & 32,8 & 31,9 & 13,8 & & \\
\hline \multirow{2}{*}{$\begin{array}{l}\text { My teachers will help me } \\
\text { improve my work if I do poorly } \\
\text { on an assignment }\end{array}$} & 22 & 55 & 149 & 193 & 105 & \multirow{2}{*}{$\begin{array}{l}3.58 \\
4.00\end{array}$} & \multirow[t]{2}{*}{1.05} \\
\hline & 4,2 & 10,5 & 28,4 & 36,8 & 20,0 & & \\
\hline \multirow{2}{*}{$\begin{array}{l}\text { My teachers provide me with } \\
\text { lots of chances to be part of class } \\
\text { discussions or activities }\end{array}$} & 20 & 44 & 152 & 202 & 104 & \multirow{2}{*}{$\begin{array}{l}3.62 \\
4.00\end{array}$} & \multirow[t]{2}{*}{1.02} \\
\hline & 3,8 & 8,4 & 29,1 & 38,7 & 19,9 & & \\
\hline \multirow{2}{*}{$\begin{array}{l}\text { My teachers often assign } \\
\text { homework that helps me learn }\end{array}$} & 19 & 31 & 127 & 221 & 129 & \multirow{2}{*}{$\begin{array}{l}3.78 \\
4.00\end{array}$} & \multirow[t]{2}{*}{1.00} \\
\hline & 3,6 & 5,9 & 24,1 & 41,9 & 24,5 & & \\
\hline \multirow{2}{*}{$\begin{array}{l}\text { My teachers will give me extra } \\
\text { help at school outside of our } \\
\text { regular class }\end{array}$} & 33 & 51 & 153 & 181 & 108 & \multirow{2}{*}{$\begin{array}{l}3.53 \\
4.00\end{array}$} & \multirow[t]{2}{*}{1.11} \\
\hline & 6,3 & 9,7 & 29,1 & 34,4 & 20,5 & & \\
\hline \multirow{2}{*}{$\begin{array}{l}\text { Teachers at my school treat } \\
\text { students with respect. }\end{array}$} & 26 & 26 & 151 & 196 & 131 & \multirow{2}{*}{$\begin{array}{l}3.72 \\
4.00\end{array}$} & \multirow{2}{*}{1.04} \\
\hline & 4,9 & 4,9 & 28,5 & 37,0 & 24,7 & & \\
\hline \multirow{2}{*}{$\begin{array}{l}\text { Adults in this school are usually } \\
\text { willing to make the time to give } \\
\text { students extra help }\end{array}$} & 38 & 63 & 168 & 156 & 95 & 3.40 & 1.14 \\
\hline & 7,3 & 12,1 & 32,3 & 30,0 & 18,3 & 3.00 & \\
\hline Question Items & & igful & mpc & $\begin{array}{l}\text { ork } \\
?\end{array}$ & $s$ & ow & \\
\hline
\end{tabular}




\begin{tabular}{|l|l|l|l|l|l|l|l|}
\hline & Never & Seldom & $\begin{array}{l}\text { Some- } \\
\text { times }\end{array}$ & Often & $\begin{array}{l}\text { Almos } \\
\text { t } \\
\text { always }\end{array}$ & $\begin{array}{l}\text { M/ } \\
\text { MD }\end{array}$ & SD \\
\hline $\mathrm{N}$ & 27 & 44 & & 190 & 161 & 3.78 & 1.12 \\
\hline$\%$ & 5,1 & 8,3 & 20.2 & 35,9 & 30,4 & 4.00 & \\
\hline \multicolumn{7}{l|}{ M of the domain }
\end{tabular}

*1. Strongly disagree; 2 . Disagree; 3. Partially agree; 4. Agree; 5 . Strongly agree

Students participating in this study exhibited a moderately high estimation of the manner in which their teachers organized their teaching and learning activities $(M=3.60, S D=0.69)$. Between $47 \%$ and $75 \%$ of the respondents chose "agree," "strongly agree," "often," or "almost always" to all the items in this domain, especially: "My teachers give me a lot of encouragement" $(M=3.67, S D=1.04)$, "My teachers often assign homework that helps me learn" $(M=3.78, S D=1.00)$, "Teachers at my school treat students with respect" $(M=3.72$, $S D=1.04)$, and "Thinking back over the past year in school, I felt that the school work that I was assigned was significant and important” $(M=3.78, S D=1.12)$ (see Table 3).

The research subjects did not present a consistent evaluation of teaching and learning activities at their school as evinced by the responses to the questions, "My teachers notice when I am doing a good job and let me know about it" $(M=3.33, S D=1.07$, equivalent to $32.8 \%$ of neutral responses), "My teachers will give me extra help at school outside of our regular class" $(M=3.53, S D=1.11 ; 29.1 \%$ of the students chose the answer "Partially agree"), and also "Adults in this school are usually willing to make the time to give students extra help" $(M=$ $3.40, S D=1.14 ; 32.3 \%$ of the students answered "Partially agree"). This fact represents the students' uncertain satisfaction with regard to this field.

The research data in response to the question "Thinking back over the past year in school, how often did you feel that the school work you were assigned was meaningful and important?" indicated that $35.9 \%$ of the respondents felt that the school work they accomplished in last year was important and significant, $30.4 \%$ thought that it was very important and very significant, and $20.2 \%$ attributed a very high significance to the work they achieved in school.

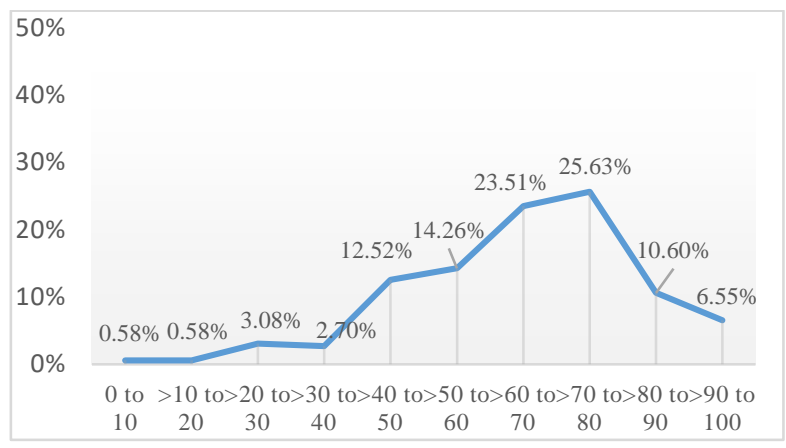

Fig. 2. Score distribution in the domain of teaching and learning

These results, presented in Fig. 2, demonstrate that students assess the domain of teaching and learning at the level of 65.1 from 100 or between 60 and 70 points (equal to $23.51 \%$ of the respondents). It can be asserted that $33.72 \%$ of the students selected different levels below this 
point; on the other hand, $42.78 \%$ or the participants find the teaching and learning activities organized by the teachers in school good or very good.

The outcomes of the characteristics of the different subgroups obtained from the analyses of the Independent Sample T-test and the one-way ANOVA yield the realization that no statistically significant differences can be found between boys and girls with regard to the specific activities of teaching and learning at school. Both boys and girls share the same point of view on the support, encouragement, and knowledge reinforcing activities organized by teachers, and the volition of assistance provided by the adults at the schools.

Conversely, a statistically significant difference was found between students living in the city and those residing in the suburbs. More precisely, the groups of students from the metropolitan areas rated the support of professors out of regular hours $(M=3.66, S D=1.15)$ higher than those from the suburbs $(M=3.42, S D=1.08 ; p=.017)$. However, city-dwelling students assessed the meaning and the importance of lessons learned in previous years $(M=3.64, S D=$ $1.17)$ to be lower than students from the suburbs $(M=3.90, S D=1.06 ; p=.008)$.

Students in C.G. school (in the city) evaluated the significance and importance of the lessons learned during previous years lower than those in P.C. school ( $M$ difference $=-.39 ; p=.036)$ and C.D. school ( $M$ difference $=-.48 ; p=.006)$. Bothe these schools are in the suburbs. Students in the 8th grade appraised possibilities of participation in classroom discussions or activities more highly than those in 9 th grade, with the $M$ difference score of .28 ; and $p=.025$.

\section{A moderate evaluation of interpersonal relationships in school}

Table IV. Mean Score and Frequency of Students' Responses in the Domain of Interpersonal

Relationships

\begin{tabular}{|c|c|c|c|c|c|c|c|}
\hline \multirow{3}{*}{$\begin{array}{l}\text { Question Items } \\
(\alpha=.85)\end{array}$} & \multicolumn{7}{|c|}{ DOMAIN: Student Relationships Score $=\mathbf{5 6 , 5}$} \\
\hline & \multicolumn{5}{|c|}{ Response category $(\mathrm{N} / \%)^{\mathrm{a}}$} & \multirow{2}{*}{$\begin{array}{l}M / \\
M D\end{array}$} & \multirow[t]{2}{*}{$S D$} \\
\hline & 1 & 2 & 3 & 4 & 5 & & \\
\hline \multirow{2}{*}{$\begin{array}{l}\text { Students in my school treat } \\
\text { each other with respect }\end{array}$} & 37 & 108 & 230 & 105 & 50 & \multirow{2}{*}{$\begin{array}{l}3.04 \\
3.00\end{array}$} & \multirow[t]{2}{*}{1.03} \\
\hline & 7,0 & 20,4 & 43,4 & 19,8 & 9,4 & & \\
\hline \multirow{2}{*}{$\begin{array}{l}\text { Students at this school are often } \\
\text { bullied }\end{array}$} & 99 & 143 & 146 & 68 & 66 & \multirow{2}{*}{$\begin{array}{l}2.73 \\
3.00\end{array}$} & \multirow[t]{2}{*}{1.26} \\
\hline & 19,0 & 27,4 & 28,0 & 13,0 & 12,6 & & \\
\hline \multirow{2}{*}{$\begin{array}{l}\text { Students at this school are often } \\
\text { teased or picked on }\end{array}$} & 92 & 145 & 148 & 85 & 56 & \multirow{2}{*}{$\begin{array}{l}2.75 \\
3.00\end{array}$} & \multirow[t]{2}{*}{1.22} \\
\hline & 17,5 & 27,6 & 28,1 & 16,2 & 10,6 & & \\
\hline \multirow{2}{*}{$\begin{array}{l}\text { Harassment, intimidation and } \\
\text { bullying by other students are a } \\
\text { problem at my school }\end{array}$} & 127 & 169 & 119 & 59 & 55 & \multirow{2}{*}{$\begin{array}{l}2.52 \\
2.00\end{array}$} & \multirow[t]{2}{*}{1.26} \\
\hline & 24,0 & 31,9 & 22,5 & 11,2 & 10,4 & & \\
\hline \multicolumn{6}{|l|}{$M$ of the domain } & 2.76 & 0.80 \\
\hline
\end{tabular}

*1. Strongly disagree; 2 . Disagree; 3 . Partially agree; 4. Agree; 5 . Strongly agree

The quality of social bonds between students was queried in this study via the four items presented in Table 4. Since this domain included negative items, the higher score represented a lesser quality of the bonds between students and a lower sense of well-being at the school. It may thus be claimed that in principle, the relationships between students at school are rather good, with the $M$ value of the domain calculated as $2.76(S D=0.80)$. About $40 \%$ of students 
agreed partially to the item "Students in my school treat each other with respect." Around a quarter (equivalent to $27.4 \%$ ) of the students responded that they disagreed with or did not quite agree with the statement that their classmates at school respect each other. Such lack of respect is partly reflected in the proportion of $21 \%$ and $27 \%$ of the students who reported the existence of taunting, teasing, harassment, intimidation, and bullying by their peers. Therefore, it is clear that the learning environment of the respondents for this study also encompassed issues related to bullying or some form of physical or psychological violence against other students in the schools.

Indeed, the total score for this domain was 56.5, placed in the range of 50 to 60 points, amounting to $10.51 \%$ of the respondents. The scores reflect the extent to which relationships among students are open, honest, and respectful. $40.86 \%$ of the responses were placed at the 0 to 50 deciles, and indicated positive results rather than negative and preventable outcomes such as bullying, harassment, and intimidation (see Fig. 3). As with the previous domains, however, it must be noted that a considerable proportion of the responses were located at the neutral interval (see Table 4). Specifically, more than $40 \%$ of the students were indeterminate with regard to the quality of these bonds and the problems concerning peer relationships.

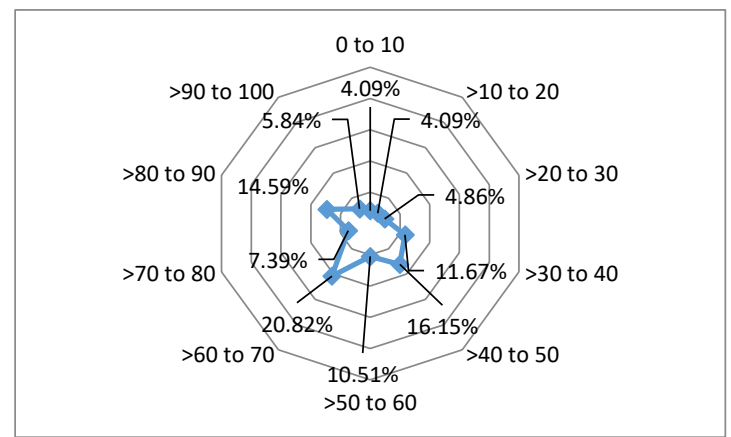

Fig. 3. Score distribution of the domain of student relationships

Once again, no statistically significant difference was discovered between boys and girls; but the difference was statistically significant for suburban and urban subgroups, with $t(509)=-$ $2.249, p=.025$. Students in the suburbs $(M=2.85, S D=1.19)$ agreed more with the statement that they were bullied at school than those in the urban areas $(M=2.59, S D=1.34)$.

The one-way ANOVA revealed a statistically significant difference with $p<.05$ between various groups of subjects according to different variables. In particular, students in C.G. and P.C. schools appraised mutual respect higher than those in D.V. and C.D. schools. Students in C.G. and P.C. schools manifested a lower level of dissatisfaction due to the phenomenon of bullying than those of C.D. and D.V. schools. Students of C.D. and D.V. schools expressed higher degrees of dissatisfaction about facing mockery, teasing, bullying, and harassment by peers than the students of C.G. school. The students who were good at learning evinced lower levels of disagreement with instances of bullying and mockery in school than moderate students, with $p$-values of .008 and .034. In comparison to the responses of students of $8^{\text {th }}$ and $9^{\text {th }}$ grades, the students of $7^{\text {th }}$ grade noted lower levels of mutual respect in the school 
environment. Students of the $8^{\text {th }}$ grade displayed less satisfaction with bullying than those in the $7^{\text {th }}$ and $9^{\text {th }}$ grades.

Table V. Mean Score and Frequency of Students' Responses in the Domain of Emotional Environment

\begin{tabular}{|c|c|c|c|c|c|c|c|}
\hline \multirow{3}{*}{ Question Items } & \multicolumn{7}{|c|}{ DOMAIN: Emotional Environment Score $=\mathbf{5 8 , 3}$} \\
\hline & \multicolumn{5}{|c|}{ Response category $(\mathrm{N} / \%)^{\mathrm{a}}$} & \multirow{2}{*}{$\begin{array}{c}M / \\
M D\end{array}$} & \multirow[t]{2}{*}{ SD } \\
\hline & 1 & 2 & 3 & 4 & 5 & & \\
\hline \multirow{2}{*}{$\begin{array}{l}\text { My school has clear rules } \\
\text { and consequences for } \\
\text { behavior }\end{array}$} & 14 & 16 & 61 & 235 & 202 & \multirow{2}{*}{$\begin{array}{l}4.13 \\
4.00\end{array}$} & \multirow[t]{2}{*}{0.92} \\
\hline & 2,7 & 3,0 & 11,6 & 44,5 & 38,3 & & \\
\hline \multirow{2}{*}{$\begin{array}{l}\text { Most students in my school } \\
\text { do their best, even when } \\
\text { their work is difficult }\end{array}$} & 53 & 86 & 255 & 103 & 33 & \multirow{2}{*}{$\begin{array}{l}2.96 \\
3.00\end{array}$} & \multirow[t]{2}{*}{1.00} \\
\hline & 10,0 & 16,2 & 48,1 & 19,4 & 6,2 & & \\
\hline \multirow{2}{*}{$\begin{array}{l}\text { Most students in my school } \\
\text { do all their homework }\end{array}$} & 31 & 112 & 234 & 110 & 45 & \multirow{2}{*}{$\begin{array}{l}3.05 \\
3.00\end{array}$} & \multirow[t]{2}{*}{0.99} \\
\hline & 5,8 & 21,1 & 44,0 & 20,7 & 8,5 & & \\
\hline \multirow{2}{*}{$\begin{array}{l}\text { Most students in my school } \\
\text { think it is OK to cheat if the } \\
\text { other students are cheating. }\end{array}$} & 125 & 162 & 120 & 64 & 52 & \multirow{2}{*}{$\begin{array}{l}2.53 \\
2.00\end{array}$} & \multirow[t]{2}{*}{1.25} \\
\hline & 23,9 & 31,0 & 22,9 & 12,2 & 9,9 & & \\
\hline \multirow{2}{*}{$\begin{array}{l}\text { Most students in my school } \\
\text { try to do a good job on } \\
\text { schoolwork even when it is } \\
\text { not interesting }\end{array}$} & 42 & 94 & 181 & 147 & 68 & \multirow{2}{*}{$\begin{array}{l}3.20 \\
3.00\end{array}$} & \multirow[t]{2}{*}{1.12} \\
\hline & 7,9 & 17,7 & 34,0 & 27,6 & 12,8 & & \\
\hline \multirow{2}{*}{$\begin{array}{l}\text { Most students in my school } \\
\text { are well-behaved }\end{array}$} & 37 & 63 & 210 & 120 & 103 & \multirow{2}{*}{$\begin{array}{l}3.35 \\
3.00 \\
\end{array}$} & \multirow[t]{2}{*}{1.13} \\
\hline & 6,9 & 11,8 & 39,4 & 22,5 & 19,3 & & \\
\hline \multirow{2}{*}{$\begin{array}{l}\text { Most students in my school } \\
\text { do not really care about each } \\
\text { other }\end{array}$} & 67 & 162 & 195 & 76 & 30 & \multirow{2}{*}{$\begin{array}{l}2.70 \\
3.00\end{array}$} & \multirow[t]{2}{*}{1.05} \\
\hline & 12,6 & 30.6 & 36,8 & 14,3 & 5,7 & & \\
\hline \multirow{2}{*}{$\begin{array}{l}\text { Most students in my school } \\
\text { help each other when asked. }\end{array}$} & 30 & 75 & 234 & 128 & 65 & \multirow{2}{*}{$\begin{array}{l}3.23 \\
3.00\end{array}$} & \multirow[t]{2}{*}{1.02} \\
\hline & 5,6 & 14,1 & 44,0 & 24,1 & 12,2 & & \\
\hline Most students in my school & 30 & 64 & 227 & 135 & 78 & 3.31 & 1.04 \\
\hline treat each other well & 5,6 & 12,0 & 42,5 & 25,3 & 14,6 & 3.00 & \\
\hline Students are treated fairly by & 38 & 80 & 128 & 190 & 92 & 3.41 & 1.15 \\
\hline the adults in the school. & 7,2 & 15,2 & 24,2 & 36.0 & 17,4 & 4.00 & \\
\hline Most students in my school & 27 & 89 & 200 & 153 & 55 & 3.23 & 1.02 \\
\hline $\begin{array}{l}\text { are easily able to work out } \\
\text { disagreements with other } \\
\text { students. }\end{array}$ & 5,2 & 17,0 & 38,2 & 29,2 & 10,5 & 3.00 & \\
\hline There are lots of chances for & 40 & 71 & 190 & 159 & 67 & 3.27 & 1.09 \\
\hline $\begin{array}{l}\text { students in my school to talk } \\
\text { with a teacher one-on-one }\end{array}$ & 7,6 & 13,5 & 36,1 & 30,2 & 12,7 & 3.00 & \\
\hline Adults in this school apply & 38 & 92 & 198 & 132 & 66 & 3.18 & 1.09 \\
\hline $\begin{array}{l}\text { the same rules to all students } \\
\text { equally }\end{array}$ & 7,2 & 17,5 & 37,6 & 25,1 & 12,5 & 3.00 & \\
\hline My teachers really care & 27 & 45 & 180 & 165 & 105 & 3.53 & 1.07 \\
\hline about me & 5,2 & 8,6 & 34,5 & 31,6 & 20,1 & 4.00 & \\
\hline$M$ the domain & & & & & & 3.22 & $\mathbf{0 . 4 5}$ \\
\hline
\end{tabular}

*1. Strongly disagree; 2 . Disagree; 3. Partially agree; 4. Agree; 5. Strongly agree 
The importance of the emotional ambiance must also be considered with regard to interpersonal relationships and their effect on a student's sense of well-being while in the school environment. This domain pertains to attitudes toward the social environment, and its total obtained score was 58.3. This items for this field included the respondents' perceptions of the manners in which students ought to conduct themselves in the academic environment and how they actually do behave. The items also tested the respondents' general opinions with regard to the fairness of the school. The scores of this domain averaged $3.22(S D=0.45)$ and most items achieved an average mark that was very close to the neutral level of "Partially agree." The proportion of responses representing the viewpoint of "Agree/ Strongly agree" and "Disagree/ Strongly disagree" were equal and exhibited an ambivalent attitude and avoidance in a quarter of the students who participated in this study (see Table 5).

Despite the above outcome, the respondents highly appreciated that students must respect the rules or suffer the consequences of their negative behaviors in this social environment $(M=$ 4.13, $S D=0.92$ ). $82.8 \%$ of the respondents selected the answers "Agree" and "Strongly agree" to the statement "My school has clear rules and consequences for behavior." However, it must be highlighted that around $22.1 \%$ of the students agreed /strongly agreed to the opinion that "Most students in my school think it is OK to cheat if the other students are cheating" and 20\% of students agreed /strongly agreed to the statement, "Most students in my school do not really care about each other." Furthermore, young people evaluated the preoccupation, interest, and circumspection of their teachers at school in a positive manner $(M=3.53, S D=1.07) .31 .6 \%$ of the participants chose the answer "agree" and $20.1 \%$ responded "strongly agree" to the item "My teachers really care about me."

The comparison of means effected according to the Levene statistical method between the two subgroups based on the place of residence showed a significant difference between students in the city and those in the suburbs with regard to two issues: first, students living in the city ( $M$ $=3.12, S D=1.03$ ) expressed less satisfaction with their classmates' treatment of others than students living in the suburbs $(M=3.39, S D=1.01)$ at $t(509)=-2.166$ and $p=.031$; second, the city-dwelling students conversely $(M=3.35, S D=1.09)$ agreed more with the statement that "Most students in my school are easily able to work out disagreements with other students" than the suburban students $(M=3.12, S D=0.96)$, with $t(499)=2.480, p=.013$. Similarly, a significant difference was also discovered between the subgroup of boys $(M=3.46, S D=1.10)$ and the subgroup of girls $(M=3.19, S D=0.99)$ with regard to the item "Most students in my school treat each other well" with $t(513)=2.902, p=.004$.

A comparison of the averages of the subgroups of students according to different variables such as learning ability, classes, schools, and so on, leads to some vital questions that demand answers. Do students in the lower classes and of lower ages underestimate their peers and their teachers because of their maladjustment at school? Does their fresh affiliation to middle school make students feel that this new environment does not really foster the favorable emotions of fairness, or attitudes of being indispensable with regard to themselves, other students, teachers, and other adults at school? 
The quantitative data demonstrate that students who perform well academically, $(M=2.99, S D$ $=1.05)$ scored 3 points $=$ partially agree for the statement that most students made the effort to achieve the best learning outcomes, even if the studies were not interesting. This mark was lower than the perception of students who had more moderate learning outcomes $(M=3.37$, $S D=1.07)$, at $p=.005$. Although the averages of these two subgroups do not veer too much from the "partially agree" response, the mean score of higher performing students is below this point while the average mark of moderate students is higher than this point. This outcome shows that good students tend to focus more on the learning activities that inspire them whereas moderate students are likely to be more interested in activities, even if they are obligatory, and even if the children do not like them too much.

\section{Parental supports is positively evaluated}

Table VI. Mean Score and Frequency of Students' Responses in the Domain of Parental Support

\begin{tabular}{|c|c|c|c|c|c|c|c|}
\hline \multirow{3}{*}{ Question Items } & \multicolumn{7}{|c|}{ DOMAIN: Parental Support Score $=\mathbf{7 5 , 5}$} \\
\hline & \multicolumn{5}{|c|}{ Response category $(\mathrm{N} / \%)^{\mathrm{a}}$} & \multirow{2}{*}{$\begin{array}{l}M / \\
M D\end{array}$} & \multirow[t]{2}{*}{$S D$} \\
\hline & 1 & 2 & 3 & 4 & 5 & & \\
\hline \multirow{2}{*}{$\begin{array}{l}\text { My family wants me to do well } \\
\text { in school }\end{array}$} & 12 & 12 & 50 & 201 & 252 & 4.27 & \multirow[t]{2}{*}{0.89} \\
\hline & 2,3 & 2,3 & 9,5 & 38,1 & 47,8 & 4.00 & \\
\hline \multirow{2}{*}{$\begin{array}{l}\text { My parents ask if I've gotten } \\
\text { my homework done }\end{array}$} & 23 & 35 & 128 & 184 & 156 & 3.79 & \multirow[t]{2}{*}{1.07} \\
\hline & 4,4 & 6,7 & 24,3 & 35,0 & 29,7 & 4.00 & \\
\hline \multirow{2}{*}{$\begin{array}{l}\text { My parents would punish me if } \\
\text { they found out I skipped school }\end{array}$} & 42 & 26 & 78 & 120 & 256 & 4.00 & \multirow[t]{2}{*}{1.25} \\
\hline & 8,0 & 5,0 & 14,9 & 23,0 & 49,0 & 4.00 & \\
\hline \multicolumn{6}{|l|}{$M$ of the domain } & 4.02 & 0.80 \\
\hline
\end{tabular}

*1. Strongly disagree; 2 . Disagree; 3. Partially agree; 4. Agree; 5. Strongly agree

The analysis of the data collected for this study revealed that of the seven principal domains pertaining to academic satisfaction, the domain of parental support achieved the highest score: 75.5 point out of a possible 100 . The mean score for this domain amounted to $4.02, S D=0.80$. The results presented in Table 6 show that $86 \%$ of the students agreed or strongly agreed with the statement "My family wants me to do well in school" $(M=4.27, S D=0.89)$. Approximately $64.7 \%$ of the respondents asserted that their parents monitored whether or not they had completed their homework $(M=3.79, S D=1.07)$, and $72 \%$ of the children agreed that they would be punished by their parents if they dropped out of school $(M=4.00, S D=1.25)$.

This domain examined the extent to which parents and members of the school community shared academic and social concerns and included the evaluation of the effectiveness of the family-school communication processes. It also assessed the level of family support for the learning activities performed by the students. The scores obtained by this field ranged between 70 and 80 on a scale of 100 (accounting for $16.02 \%$ of the responses). $14.1 \%$ of the students' answers scored less than 50 and $48.07 \%$ of the responses registered marks over 80 (see Fig. 4). 


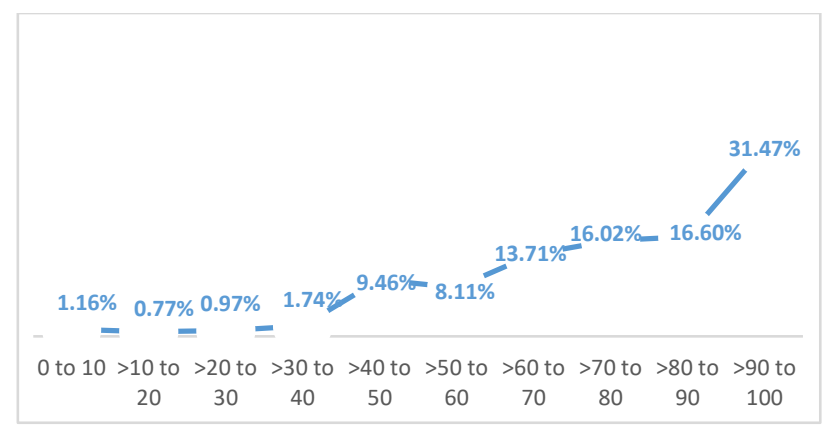

Fig. 4. Score distribution of the domain of parental supports

\section{E. Some students suffer}

The analysis of the spirit and judgment of the students in the school environment yielded the results presented in Table 7, which confirm that in general the respondents revealed a neutral attitude denoted by $M=3.12, S D=0.52$ on all nine items of the field querying the morale prevalent in the school environment. This "equivocal" attitude is translated perhaps into the subjective assessment of students with regard to opportunities of expressing themselves at school ( $M=3.24, S D=1.04,40.6 \%$ neutral responses) and their feelings of belonging to the school $(M=3.56, S D=1.08,36.4 \%$ "partially agree"). Around $34.5 \%$ of the students felt that teachers and other adults at school did not always listen to their ideas $(M=3.31, S D=1.15)$, implying that they did not have access to much opportunity for self-expression in the school environment and that they were dissatisfied with the prevailing circumstances.

Table VII. Mean Score and Frequency of Students' Responses in the Domain of the Morale in the

School Community

\begin{tabular}{|c|c|c|c|c|c|c|c|c|c|}
\hline \multirow{3}{*}{ Question Items } & \multicolumn{9}{|c|}{ DOMAIN: Morale in the school community Score $=60,7$} \\
\hline & \multicolumn{7}{|c|}{ Response Category $(\mathrm{N} / \%)^{\mathrm{a}}$} & \multirow{2}{*}{$\begin{array}{l}M / \\
M D\end{array}$} & \multirow[t]{2}{*}{ SD } \\
\hline & \multicolumn{2}{|c|}{\begin{tabular}{|l} 
Neve \\
$\mathbf{r}$
\end{tabular}} & \multicolumn{2}{|c|}{ Seldom } & \begin{tabular}{|l|} 
Some \\
- \\
times
\end{tabular} & $\begin{array}{l}\text { Ofte } \\
\text { n }\end{array}$ & $\begin{array}{l}\text { Almos } \\
\mathrm{t} \\
\text { always }\end{array}$ & & \\
\hline \multirow{2}{*}{$\begin{array}{l}\text { Thinking back over the past } \\
\text { year in school, how often did } \\
\text { you enjoy being in school? }\end{array}$} & \multicolumn{2}{|l|}{18} & \multicolumn{2}{|l|}{48} & 138 & 217 & 104 & \multirow{2}{*}{$\begin{array}{l}3.65 \\
4.00\end{array}$} & \multirow[t]{2}{*}{1.01} \\
\hline & \multicolumn{2}{|c|}{3,4} & \multicolumn{2}{|l|}{9,1} & 26,3 & 41,3 & 19,8 & & \\
\hline \multirow{2}{*}{$\begin{array}{l}\text { Thinking back over the past } \\
\text { year in school, how often did } \\
\text { you hate being in school? }\end{array}$} & \multicolumn{2}{|c|}{129} & \multicolumn{2}{|c|}{192} & 133 & 38 & 33 & 2.34 & \multirow[t]{2}{*}{1.11} \\
\hline & \multicolumn{2}{|c|}{24,6} & \multicolumn{2}{|c|}{36,6} & 25,3 & 7,2 & 6,3 & 2.00 & \\
\hline \multicolumn{2}{|l|}{ Question Items } & \multicolumn{2}{|l|}{1} & 2 & 3 & 4 & 5 & $\begin{array}{c}M / \\
M D\end{array}$ & $S D$ \\
\hline \multirow{2}{*}{\multicolumn{2}{|c|}{$\begin{array}{l}\text { Students have lots of chances in } \\
\text { my school to get involved in } \\
\text { sports, clubs and other school } \\
\text { activities outside of class }\end{array}$}} & \multirow{2}{*}{\multicolumn{2}{|c|}{$\frac{32}{6,0}$}} & 30 & 149 & 177 & 145 & 3.70 & 1.11 \\
\hline & & & & 5,6 & 28,0 & 33,2 & 27,2 & 4.00 & \\
\hline I have opportunities to express & & 32 & & 77 & 215 & 139 & 66 & 3,24 & 1.04 \\
\hline myself at school & & 6,0 & & 14,6 & 40,6 & 26,3 & 12,5 & 3,00 & \\
\hline Students help decide what goes or & & 57 & & 115 & 199 & 98 & 45 & 2,92 & 1.10 \\
\hline in my school & & 11 , & & 22,4 & 38,7 & 19,1 & 8,8 & 3,00 & \\
\hline I wish I went to a different school & & 177 & & 161 & 97 & 28 & 54 & 2,27 & 1.27 \\
\hline & & 34,2 & & 31,1 & 18,8 & 5,4 & 10,4 & 2,00 & \\
\hline & & 56 & & 91 & 194 & 136 & 45 & 3,04 & 1.10 \\
\hline
\end{tabular}




\begin{tabular}{|c|c|c|c|c|c|c|c|}
\hline $\begin{array}{l}\text { In my school, students have lots of } \\
\text { chances to help decide things, like } \\
\text { activities and rules }\end{array}$ & 10,7 & 17,4 & 37,2 & 26,1 & 8,6 & 3,00 & \\
\hline \multirow[t]{2}{*}{ I feel like I belong at this school } & 31 & 33 & 193 & 156 & 117 & \multirow{2}{*}{$\begin{array}{l}3,56 \\
4,00\end{array}$} & \multirow[t]{2}{*}{1.08} \\
\hline & 5,8 & 6,2 & 36,4 & 29,4 & 22,1 & & \\
\hline \multirow{2}{*}{$\begin{array}{l}\text { Teachers and other adults here } \\
\text { listen to students' ideas about the } \\
\text { school }\end{array}$} & 48 & 62 & 181 & 148 & 86 & \multirow{2}{*}{$\begin{array}{l}3,31 \\
3,00\end{array}$} & \multirow[t]{2}{*}{1.15} \\
\hline & 9,1 & 11,8 & 34,5 & 28.2 & 16,4 & & \\
\hline \multicolumn{6}{|l|}{$M$ of the domain } & 3.12 & 0.52 \\
\hline
\end{tabular}

*1. Strongly disagree; 2. Disagree; 3. Partially agree; 4. Agree; 5. Strongly agree

A faction of students did not positively estimate their abilities of assisting in the making of decisions about the school community $(M=2.92, \mathrm{SD}=1.01,38.7 \%$ neutral answers $)$ or about selecting activities and contributing to the creation of school rules $(M=3.04, S D=1.10,37.2 \%$ neutral responses). Also, $34.5 \%$ of the respondents did not know whether or not their concerns were heard.

Most of students liked being in school (61.1\%) and did not want to change their school $(63.3 \%)$ (see Table 7). This assertion was proved by the $M$ score, which was close to the rank of 4 or the response of "Often" $(M=3.65, S D=1.01)$ to the question "Thinking back over the past year in school, how often did you enjoy being in school?"

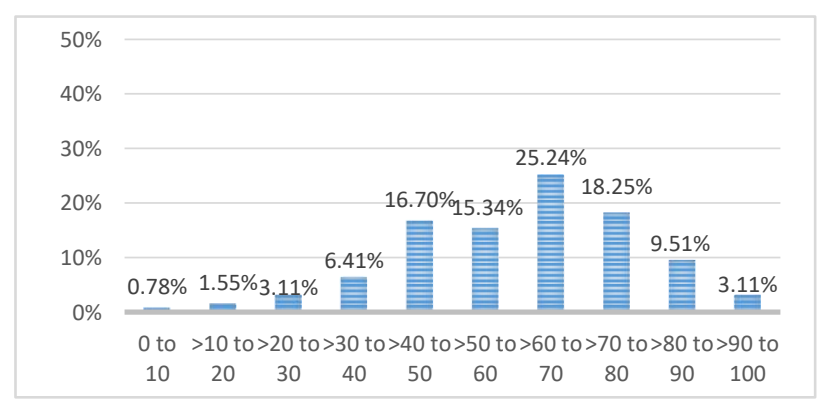

Fig. 5. Score distribution of the domain of the morale in the school community

This field checks for the property of high morale and the student's identification with the central features of the school. It also ascertains the feeling of belonging inculcated in all the parties engaged with the school. By considering the school as a common cause, this domain assessed the ability of school authorities to provide practical services and to consolidate the school community toward healthy and positive outcomes. The obtained score of 60.7/100 for this field indicated that the students were positively inclined toward the school leadership. $25.24 \%$ of the responses were classified within the range of 60 to $70 ; 30.87 \%$ were placed higher, and $43.89 \%$ of the students' answers ranged from 0 to 60 (see Fig. 5).

A comparison of the $M$ scores of two subgroups using the Levene test for the sex and residence variables showed that students in the city $(M=3.84, S D=1.01)$ were more enthusiastic about opportunities they were accorded to participate in sports, clubs, and extracurricular activities organized by the school than students in the suburbs $(M=3.59, S D=1.16, p=.012)$. Boys $(M$ $=3.44, S D=1.17)$ appreciated the positive listening abilities of the teachers and adults in their schools more than girls $(M=3.18, S D=1.11, p=.011)$. 
The results of the one-factor ANOVA demonstrated statistically significant differences between the groups of students with regard to different independent variables such as the school, class, and academic performance. Also, students from city schools were more satisfied than those in the suburbs about possibilities of participating in school activities (sports, clubs, and other extracurricular events). Students in $7^{\text {th }}$ grade were less contented with the school climate than those in the $8^{\text {th }}$ and $9^{\text {th }}$ grades. With respect to academic performance, gifted students felt happier at school and liked to belong to their school more than students who were more moderate in their educational achievements, and so the latter group was more likely to want to move to another school than the first $(p=.012)$.

Table VIII. Mean Score and Frequency of Students' Responses in the Domain of School Safety

\begin{tabular}{|c|c|c|c|c|c|c|c|}
\hline \multirow{3}{*}{ Question Items } & \multicolumn{7}{|c|}{ DOMAIN : School Safety Score $=65,1$} \\
\hline & \multicolumn{5}{|c|}{ Response Category (N/\%) } & \multirow{2}{*}{$\begin{array}{c}M / \\
M D\end{array}$} & \multirow[t]{2}{*}{$S D$} \\
\hline & 1 & 2 & 3 & 4 & 5 & & \\
\hline \multirow{3}{*}{$\begin{array}{l}\text { I sometimes stay home } \\
\text { because I do not feel safe at } \\
\text { school }\end{array}$} & 175 & 177 & 86 & 43 & 39 & \multirow{2}{*}{$\begin{array}{l}2.22 \\
2.00\end{array}$} & \multirow[t]{2}{*}{1.21} \\
\hline & 33,7 & 34,0 & 16,5 & 8,3 & 7,5 & & \\
\hline & $\begin{array}{l}\text { Not } \\
\text { safe }\end{array}$ & $\begin{array}{l}\text { Some } \\
\text { - } \\
\text { what } \\
\text { safe }\end{array}$ & \multicolumn{2}{|c|}{$\begin{array}{l}\text { Mostly } \\
\text { safe }\end{array}$} & $\begin{array}{l}\text { Very } \\
\text { safe }\end{array}$ & $\begin{array}{c}M / \\
M D\end{array}$ & $S D$ \\
\hline \multirow{2}{*}{$\begin{array}{l}\text { How safe do you feel outside } \\
\text { around the school? }\end{array}$} & 50 & 138 & \multicolumn{2}{|c|}{254} & 89 & 2.72 & \multirow[t]{2}{*}{0.85} \\
\hline & 9,4 & 26,0 & \multicolumn{2}{|c|}{47,8} & 16,8 & 3.00 & \\
\hline \multirow{2}{*}{$\begin{array}{l}\text { How safe do you feel in the } \\
\text { hallways and restrooms of the } \\
\text { school? }\end{array}$} & 78 & 109 & 2 & & 111 & 2.71 & \multirow{2}{*}{0.96} \\
\hline & 14,7 & 20.6 & & & 21,0 & 3.00 & \\
\hline \multirow{2}{*}{$\begin{array}{l}\text { How safe do you feel in your } \\
\text { classes? }\end{array}$} & 29 & 58 & 1 & & 262 & 3.27 & \multirow[t]{2}{*}{0.87} \\
\hline & 5,5 & 11,0 & & & 49,6 & 3.00 & \\
\hline \multicolumn{6}{|l|}{ M of the domain } & 2.73 & 0.56 \\
\hline
\end{tabular}

*1. Strongly disagree; 2. Disagree; 3. Partially agree; 4. Agree; 5. Strongly agree

The descriptive results relating to school safety are presented in Table 8 and these outcomes manifested that $67.7 \%$ of research population did not agree or strongly agree with the statement "I sometimes stay home because I don't feel safe at school" $(M=2.22, S D=1.21)$. In other words, most of students expressed confidence with regard to the safety of the school environment, which included the classrooms $(M=3.27, S D=0.87)$ as well as the school's surrounding areas $(M=2.72, S D=0.85)$, the hallways, and the restrooms, which are the locations where school violence or abuse can easily occur $(M=2.71, S D=0.96)$. However, around $14.7 \%$ of the students did not feel safe at school, in the hallways, and in the restrooms; $5.5 \%$ of students mentioned the lack of security in classrooms; and $9.4 \%$ of the respondents reported that they did not feel safe in the school's external environment. 


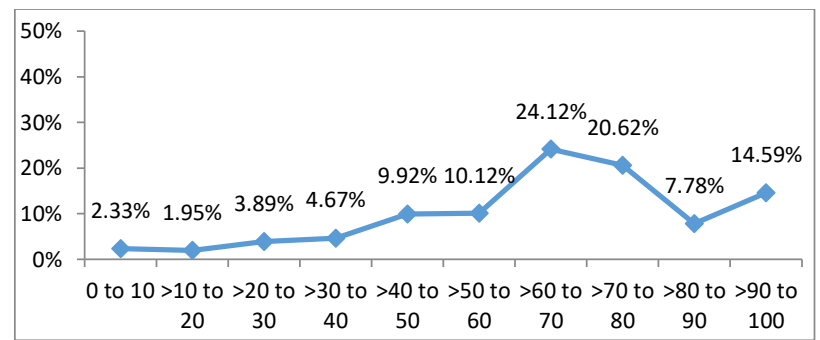

Fig. 6. Score distribution of the domain of school safety

The total score obtained for the domain examining students' sense of physical safety in and around the school was 65.1 out of a possible 100 . Thus, $44.74 \%$ of the students placed school safety between the 60 and 80 mark, which is also the range selected by the majority of the respondents. The span between the points of 80 and 100 was represented by $22.37 \%$ and the points below 50 were chosen by $22.76 \%$ of studied population (see Fig. 6).

The independent sample T-test analysis exhibited a difference with $p$-value $=.034$ in the bearing on the safety of the environment around the school between students in the city $(M=2.81, S D$ $=0.88)$ and those in the suburbs $(M=2.65, S D=0.81)$. The one-factor ANOVA indicated that gifted students felt less safe at school than the other subgroups of students at varied learning levels $(p<.05)$. Students with low achievement averages felt more insecure in the school environment than the gifted students $(p=.043)$.

\section{Discussion and Conclusion}

Data for this study were collected via a survey conducted in Hanoi, Vietnam. The questionnaires were filled individually by students under the supervision of an investigator external to the school, which allowed researchers to approximate the respondents' image their school environment and the hierarchy that they establish with regard to the different dimensions of their school environment. These results are directly suited to the research areas of school well-being, bonding, physical and emotional environment, feeling of safety, relationships, learning activities, and morale in the school community. The assessment of school climate is, as a whole, significantly correlated to the evaluation of the school in relation to the assessment of the quality of different types of interpersonal relationships: with teachers, with parents, and between students.

In general, the level of school climate remains intermediate, implying that students do express a certain amount of satisfaction with their schools, but that the sense of contentment is not too high.

It is concluded from the descriptive analyses presented above that of the seven primary domains, social relationships, physical surroundings, and emotional environment were the three aspects that did not evoke much satisfaction in the participating students. Specifically, between a quarter and a fifth of the students reported being victims of bullying, taunting, teasing or mentioned harassment, intimidation, and bullying among students. Hence, issues related to bullying or other types of physical or psychological violence against students still exist in the learning environment. A fifth of the studied students expressed the absence of a feeling of belonging to 
their school as a place where they could manifest themselves, be appreciated, and be justly treated by their classmates, their teachers, and other adults. The young people appreciated their teachers' concern, interest, and care. The measure of emotional environment included peer treatment among students, between students and teachers, students and other adults at school, the sentiment of fairness, and the way of indispensable treatment in the school. In this regard, the subgroups of students expressed different levels of satisfaction for the level of their adaptation to the learning environment depending on the different aspects of the measure and with the help of their family and their school's academic environment.

According to the subjective self-evaluation of students, the parents of this sample of participants are very interested in learning process as well as in the activities that occur both at home and in the schools. Students articulated their highest level of satisfaction for the support provided by their parents.

Indeed, most Vietnamese schools only care about the child's academic performance and accommodate students with knowledge through the system of homework and supportive learning activities in regular and extracurricular time. The schools do not really take interest in the subjective feelings of students pertaining to the construction of a really healthy, democratic, and creative atmosphere within the school and for the students. In fact, in Vietnamese traditional culture, individuality is always second to the community and this morale is a rational interpretation of the lack of encouragement for the self-expression of individual students at schools. Learners are not really the nucleus of the education and training system at Vietnamese schools. Instead, in concordance with the spirit of the Vietnamese people, adults in the form of teachers and administrators decide all relevant issues pertaining to all dimensions of a child's development. Most of these adults either do not think it necessary to or they are not willing to listen to what the child talks or thinks about. Therefore, some students do not know whether or not they have been adequately heard.

Despite everything, most students have expressed confidence in the safety of the school environment. However, there are still about some students who do not feel safe in and around the school premises and this insecurity must be addressed.

Although this study provides some interesting quantitative data about the Vietnamese school climate, it acknowledges certain limitations: first, cultural factors have not been clarified; second, no comparison of instruments has been elucidated in the process of selecting a particular methodology. Therefore, in the near future, the authors of this paper will continue to conduct further research on this issue by using other tools to highlight the cultural elements of the research object.

This study should also be extended in order to refine the understanding of the constitutive parameters of well-being at schools in Vietnam and to become a sustainable bridge for crosscultural research in the future. 


\section{Acknowledgments}

This study was financially supported by the Hanoi Department of Sciences and Technology.

\section{References}

Anderson, C. S. (1982). The search for school climate: A review of the research. Review of Educational Research, 52(3), 368-420.

Bennacer, H. (2008). Le climat social de la classe à l'école élémentaire: Elaboration et validation de la version abrégée d'une échelle. In J. M. Hoc \& Y. Corson (Éds.), Actes du Congrès 2007 de la Société Française de Psychologie (pp. 131-139). Nantes: Université de Nante. Retrieved from http://www.sfpsy.org/IMG/pdf/actes-SFP2007.pdf

Danielsen, A. G., Samdal, O., Hetland, J., \& Wold, B. (2009). School-related social support and students' perceived life satisfaction. J Educ Res., 102, 303-318.

Debarbieux, E., Anton, N., Astor, R. A., Benbenishty, R., Bisson-Vaivre, C., Cohen, J. ... \& Saltet, J. (2012). Le "Climat scolaire" : définition, effets et condition d'amélioration. Rapport au Comité scientifique de la Direction de l'enseignement scolaire, Ministère de l'éducation nationale. MEN-DGESCO/Observatoire International de la Violence à l'Ecole.

Debarbieux, E. (2011). Du «Climat scolaire »: Définition, effets et politiques publiques. Education et Formation, (88-89), 11-27.

Dorman, J. (2002). Classroom environment research: Progress and possibilities. Queensland Journal of Educational Research, 18(2), 112-140. Retrieved from http://www.iier.org.au/qjer/qjer18/dorman.html

Florin, A. (2011a). Des apprentissages fondamentaux aux compétences de demain : les apports de la psychologie de l'éducation. Bulletin de Psychologie, 64(1), 15-29.

Florin, A. (2011b). Qualité de vie et bien-être des enfants à l'école? Journal des professionnels de la petite enfance, 72, 54-55.

Fraser, B.J. (1990). Individualised Classroom Environment Questionnaire. Melbourne: Australian Council for Educational Research.

Gibbons, S. \& Silva, O. (2011). School quality, child wellbeing and parents' satisfaction, Economics of Education Review, 30(2), 312-331.

Gottfredson, G. D. \& Gottfredson, D. (1985). Victimization in schools. New-York: Plenum Press.

Guimard, P., Bacro, F. \& Florin, A. (2013). Évaluation du bien-être et de la qualité de vie à l'école. Rapport terminal de recherche. Université de Nantes.

Karatzias, A., Power, K. G., Flemming, J., Lennan, F., \& Swanson. (2002). The Role of Demographics, Personality Variables, and School Stress on Predicting School Satisfaction/Dissatisfaction: Review of the literature and research findings. Educational Psychology, 22(1), 33-50.

Lê Ngọc Văn. (2018). Hạnh phúc của nguời Việt Nam: quan niệm, thục trạng và chỉ số đánh giá, Bộ Khoa học Công nghệ Việt Nam, 2018 (Le Ngoc Van, Happiness of Vietnamese people: concepts, actual situation and assessment index, Ministry of Sciences and Technologies in Vietnam, 2018).

Purkey, S. \& Smith, M. (1983). Effective schools: A review. The Elementary School Journal, 83(4), 427-452.

Randolph, J., Kangas, M. M., \& Ruokamo, H. (2009). The Preliminary Development of the Children's Overall Satisfaction with Schooling Scale (COSSS). Child Indicators Research, 2(1), 79-93.

Rutter, M. (1983). School effects on pupil progress: research findings and policy implications. Child Development, $54,1-29$.

Samdal, O., Nutbeam, D., Wold, B. \& Kannas, L. (1998). Achieving health and educational goals through schools - a study of the importance of the school climate and the students' satisfaction with school. Health Education Research, 13(3), 383-397.

Slee, P. T., \& Skrzypiec, G. (2016). Well-being, positive peer relations and bullying in school settings. Dordrecht, The Netherlands: Springer.

Taylor, P. C., Fraser, B. J., \& Fisher, D. L. (1997). Monitoring constructivist classroom learning environments. International Journal of Educational Research, 27(4), 293-302.

Truong Thi Khanh Ha. (2015). Subjective well-being in adults. Review of Psychology, 34-38. 